\title{
Second-Order Nonlinear Optical Active Calix[4]arene Polyimides Suitable for Frequency Doubling in the UV Region
}

\author{
Paul J. A. Kenis, ${ }^{\dagger}$ Oscar F. J. Noordman, ${ }^{\ddagger}$ Niek F. van Hulst, \\ Johan F. J. Engbersen, ${ }^{\ddagger}$ and David N. Reinhoudt*, ${ }^{*}$ \\ MESA Research Institute, University of Twente, Laboratory of Supramolecular Chemistry \& \\ Technology, and Applied Optics Group, P.O. Box 217, 7500 AE Enschede, The Netherlands \\ Benno H. M. Hams and Cornelis P. J. M. van der Vorst \\ Akzo Nobel Central Research, Departments of Photonics Research and Physical Chemistry, \\ P.O. Box 9300, 6800 SB Arnhem, The Netherlands
}

Received August 7, 1996. Revised Manuscript Received December 10, $1996^{\otimes}$

\begin{abstract}
A new type of soluble calix[4]arene-based polyimides was prepared by reaction of bis(3aminopropyl) dipropyl functionalized tetranitrocalix[4]arenes with hexafluoroisopropylidene diphthalic anhydride. Spin-coating of these polymers and subsequent electric field poling results in films that are highly transparent above $410 \mathrm{~nm}$ and exhibit high and thermally stable second harmonic generation coefficients. These properties make these materials very suitable for frequency-doubling applications in the UV region $(820-410 \mathrm{~nm})$.
\end{abstract}

\section{Introduction}

Sources of laser light of short wavelength $(\lambda<500$ $\mathrm{nm}$ ) are of considerable interest for various applications, such as optical sensing and data storage. The first examples of blue lasers have been reported recently, but practical applications are still hampered by technical problems. ${ }^{1}$ Alternatively, blue laser light may be obtained by second harmonic generation of light from readily available red diode lasers. This process requires materials of high transparency in the UV region and with appreciably, stable second-order nonlinear optical (NLO) coefficients. ${ }^{2}$

Currently considerable research is directed to the development of polymeric materials with high NLO coefficients, especially for electrooptical applications. ${ }^{3,4}$ Polymeric materials have the advantage over crystalline (inorganic) materials of easier processability, e.g., thin films can be prepared by spin-coating on flat substrates, such as silicon wafers, allowing implementation in microelectronic circuits. The required noncentrosymmetric alignment of the NLO chromophores in these materials is generally obtained by electrical poling. The first examples in this field are polymers in which the NLO chromophores are dissoluted in a polymer matrix

T Laboratoyy of Supramolecular Chemistry \& Technology

* Applied Optics Group.

Abstract published in Advance ACS Abstracts, January 15, 1997.

(1) (a) Haase, M. A.; Qiu, J.; DePuydt, J. M.; Cheng. H. Appl. Phys. Lett. 1991, 59, 1272. (b) Nakamura, S.; Senoh, M.; Nagahama, S.; Iwasa, N.; Yamada, T.; Matsushita, T.; Kiyoku, H.; Sugimoto, Y.Jpn. J. Appl. Phys. 1996, 35, 74-76.

(2) Prasad, P.; Williams, D. J. Introduction to Nonlinear Optical Effects in Molecules and Polymers; John Wiley \& Sons: New York, 1991.

(3) (a) Burland, D. M.; Miller, R. D.; Walsh, C. A. Chem. Rev. (Washington, D.C.) 1994, 94, 31-75 and references therein. (b) Marks, T. J.; Ratner, M. A. Angew. Chem., Int. Ed. Engl 1995, 34, 155-173 and references therein. (c) Crumpler, E. T.; Reznichenko, J. L.; Li, D.; Marks, T. J.; Lin, W.; Lundquist, P. M., Wong, G. K. Chem. Mater. $1995,7,596$.

(A) Burland, D. M.; Millex, R. D.; Walsh, C. A. Chem. Rev. (Washington, D.C.) 1994, 94, 31 .

S0897-4756(96)00420-6 CCC: $\$ 14.00$ (the so-called solid-solution approach). ${ }^{5}$ However, high concentrations of NLO-active chromophores in the polymer are prohibited by the occurrence of segregation or centrosymmetric crystallization, giving rise to a decrease of the second-order NLO activity. Furthermore, high concentrations of chromophore can lower the glass transition temperature of the polymer, resulting in an earlier thermal relaxation of the noncentrosymmetrical structure.

A more promising approach to obtain stable NLO materials is to bind the NLO chromophores covalently to the polymer chain or in the polymer network. ${ }^{3,6}$ This method allows a higher chromophore density in the material than the solid-solution approach and the restricted motional freedom of the chromophores, especially in polymers with high glass transition temperatures, imposes a lower tendency for relaxation. However, the development of NLO-active polymers with high glass transition temperatures $\left(T_{\mathrm{g}}>150^{\circ} \mathrm{C}\right)$ that are still processable, i.e., are soluble in organic solvents commonly used for spin-coating, is not straightforward. A strategy to overcome the processability problem is to use in the spin-coating process a soluble prepolymer that can afterward be further polymerized by UV or thermal curing. Suitable for these purposes are for example polyamic acid prepolymers functionalized with NLOactive groups. After thermal curing these prepolymers yield insoluble and transparent polyimides with a high $T_{\mathrm{g} \cdot}{ }^{3,7}$

(5) Wu, J. W.; Valley, J. R.; Ermer, S.; Binkley, E. S.; Kenney, J. T.; Lipscomb, G. F.; Lytel. R. Appl. Phys. Lett. 1991, 58, 225.

(6) (a) Jungbauer, D.; Terakoka, I.; Yoon, D. Y.; Reck, B.; Swalen J. D.; Twieg, R.; Wilsson, C. G. J. Appl. Phys. 1991, 69, 8011. (b) Marturunkakul, S.; Chen, J. I.; Jeng, R. J.; Sengupta, S.; Kumar, J.; Tripathy, S. K. Chem. Mater. 1993, 5, 743. (c) Hsiue, G. H.; Kuo, J. K.; Jeng, R. J.; Chen, J. I.; Jiang, X. L.; Marturunkakul, S.; Kumar, J.; Tripathy, S. K. Chem. Mater. 1994, 6, 884. (d) Liang, Z.; Dalton, I. R.; Garner, S. M.; Kalluri, S.; Chen, A.; Steier, W. H. Chem. Mater. 1995, 7,941 . 
Also certain aromatic imide linkers have been successfully used in NLO-functionalized polyimides to improve the solubility without decreasing the $T_{\mathrm{g} .}{ }^{8,9}$ For example $\mathrm{Yu}$ et al. reported NLO-active polyimides functionalized with (dialkylamino)-p-nitro- or $p$-sulfonyl(aza-)stilbene chromophores, that have stable frequencydoubling coefficients of $10-27 \mathrm{pm} / \mathrm{V}\left(d_{33}\right.$ values, corrected for dispersion). ${ }^{70, c, d, 9}$ Such polymers may have considerable interest for application in electrooptical switching but are less suitable for generation of blue laser light $(\lambda=410 \mathrm{~nm})$ because of the substantial overlap of the generated second harmonic with the absorption band of the chromophores $\left(\lambda_{\max }=370-450\right.$ $\mathrm{nm})$.

Previously, we have found that calix[4] $\operatorname{arenes}^{10} \mathrm{sub}$ stituted with electron-donating propoxy groups at the lower rim and electron-accepting nitro groups at the upper rim exhibit high second-order hyperpolarizabili-

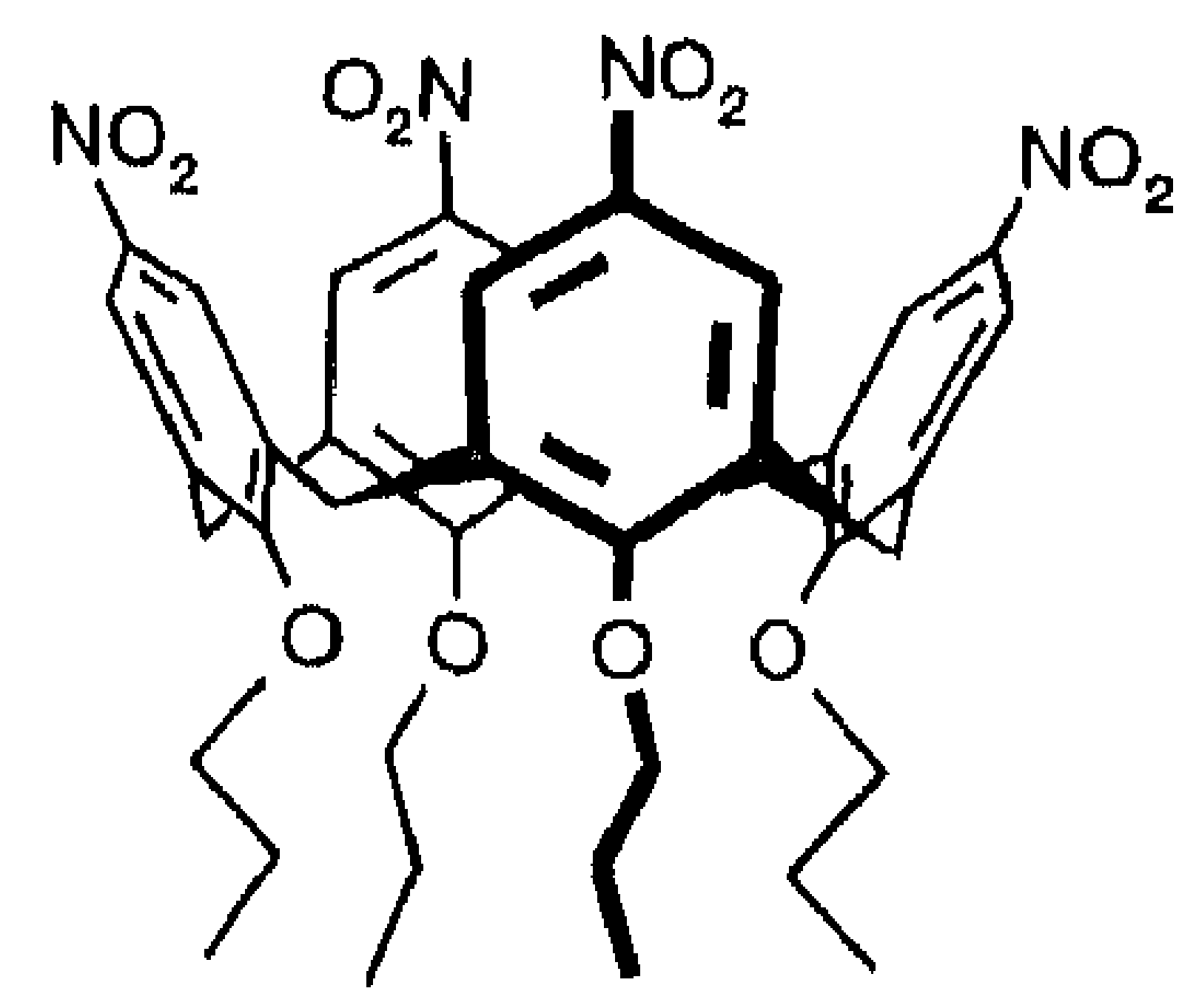

ties $\left(\beta_{z}=30 \times 10^{-30} \mathrm{esu}\right.$ at $\left.1064 \mathrm{~nm}\right)$, and are virtually transparent above $400 \mathrm{~nm} .{ }^{11}$ Moreover, due to the relatively high dipole moment $(\mu=13.8 \mathrm{D})$ these molecules can be efficiently poled in an electrical field. Poled neat films of (tetranitrotetrapropoxy)calix [4]arene exhibit high frequency-doubling coefficients $d_{33}$ that are stable at room temperature but lose most of their NLO activity at high temperatures $\left(>80^{\circ} \mathrm{C}\right) .11,12$ It was expected that covalent incorporation of the calix[4]arenes in a polymer matrix of high glass transition temperature would considerably stabilize the noncentrosymmotric alignment, obtained after poling.

In this paper the synthesis and physical characterization of a class of polyimides in which nitrocalix[4.]arenes have been incorporated in the main chain as the NLOactive groups are reported. These polymers form thermally stable and highly transparent NLO materials,

(7) (a) Bocker, M. W. Sapochak, L. S.; Ghosen, R.; Xu, C.; Dalton, L. R. Chem. Mater. 1994, 6, 104. (b) Peng, Z.; Yu, L. Macromolecules 1904, 27, 2638. (c) Yang, S.; Pong, Z,; Yu, L. Macromolecules 1994, 27, 5858. (d) Yu, D.; Yu, L. Macromolecules 1994, 27, 6718. (e) Verbiest, T.; Burland, D. M.; Jurich, M. C.; Lee, V. Y.; Miller, R. D.; Volksen, W. Macromolecules 1995, 28,3005

(8) Harris, I. W. In Polyimides; Wilson, D.; Stenzenberger, H. D.; Horgenrother, P. M., Eds,; Chapman and Hall: New York, 1990.

(9) (a) Yu, D.; Gharavi, A.; Yu, L. Macromolecules 1995, 28, 784. (b) Yu., D.; Gharavi, A.; Yu, L. J. Am. Chem. Soc. 1995, 117, 1168011686. (c) Verbiest, T.; Burland, D. M.; Jurich, M. C.; Lee, V. Y.; Miller, R. D.; Volksen, W Science 19952681604.

(10) For reasons of clarity and to reduce space, the name calix[4]arene was used instead of the original IUPAC name: pentacyclo$\left[19.3 .1 .3^{9,7}, 18,13.115,19\right]$ octacosa-1(25), $3,5,7(28), 9,11,13(27), 15,17,18(26)$,31,23 dodecane.

(11) (a) Kelderman, E.; Heesink, G. J. T.; Derhaeg, L.; Verbiest, T.; Klaase, P. T. A.; Verboom, W.; Engbersen, J. F. J.; Hulst, N. F. van; Persoons, A.; Reinhoudt, D. N. Angew. Chem., Int. Ed. Engl. 1992, 31, 1074. (b) Kelderman, E,; Derhaeg, L.; Heesink, G. J. T.; Verboom, W.; Engbersen, J. F. J.; van Hulst, N. F.; Clays, K.; Persoons, A.; Reinhoudt, D. N. Adv. Mater. 1993, 5,925 .

(12) Kenis, P. J. A.; Engbersen, J. F. J.; Reinhoudt, D. N.; et al., manuscript in preparation. which makes them especially suitable for frequency doubling in the UV region. ${ }^{13}$

\section{Experimental Section}

Synthesis. Melting points were determined with a Reichert melting point apparatus and are uncorrected. ${ }^{1} \mathrm{H}$ NMR and ${ }^{13} \mathrm{C}$ NMR spectra were recorded on a Brucker AC 250 spectrometer in $\mathrm{CDCl}_{3}$ (unless stated otherwise) using residual solvent protons or $\mathrm{Me}_{4} \mathrm{Si}$ as internal reference. Mass spectra were recorded with a Finnigan MAT 90 spectrometer using $m$-nitrobenzyl alcohol (NBA) as a matrix. Infrared spectra were recorded with a Jasco A-100 infrared spectrophotometer and absorbance spectra were measured on a Hewlett-Packard $8452 \mathrm{~A}$ diode array spectrophotometer. Elemental analyses were carried out with a Model 1106 Carlo-Erbu Strumentazione element analyzer. THF was freshly distilled from $\mathrm{Na} /$ benzophenone ketyl, hexane (petroleum ether, bp $60-80^{\circ} \mathrm{C}$ ), and $\mathrm{CH}_{2} \mathrm{Cl}_{2}$ from $\mathrm{K}_{2} \mathrm{CO}_{3}$. DMF was dried over molecular sieves $\left(4 \AA\right.$ ) for at least 3 days. NMP was distilled from $\mathrm{CaCl}_{2}$ and stored over molecular sieves (4 $\AA$ ). $\mathrm{NaH}$ was a $55-65 \%$ dispersion in mineral oil and was washed three times with $n$-hexane prior to use. Other reagents were reagent grade and were used without further purification. Flash column chromatography was performed with silica $60(0.040-0.063 \mathrm{~mm}$, 230-400 mesh) from E. Merck. All reactions were carried out in an argon atmosphere.

5,11,17,23-Tetra-tert-butyl-25,27-dipropoxy-26,28-bis(3phthalimidopropoxy)calix[4]arene (2). To a well-stirred suspension of $0.42 \mathrm{~g}(17.44 \mathrm{mmol})$ of $\mathrm{NaH}$ in $1.00 \mathrm{~mL}$ of DMF was added $4 \mathrm{~g}$ (5.46 mmol) of 5,11,17,23-tetra-tert-butyl-25,27dipropoxycalix[4]arene (1) in small portions. After $30 \mathrm{~min}, 7.8$ g (29.07 mmol) of $N$-(3-bromopropyl)phthalimide dissolved in $20 \mathrm{~mL}$ of DMF was added dropwise in $1 \mathrm{~h}$. Subsequently the mixture was stirred for $20 \mathrm{~h}$ at $70^{\circ} \mathrm{C}$. After cooling to room temperature and addition of $10 \mathrm{~mL}$ of $\mathrm{H}_{2} \mathrm{O}$, the DMF was removed by evaporation. The residue was taken up in $\mathrm{CH}_{2} \mathrm{Cl}_{2}$ $(200 \mathrm{~mL})$, washed with $1 \mathrm{~N} \mathrm{HCl}(2 \times 50 \mathrm{~mL})$ and brine $(2 \times$ $50 \mathrm{~mL}$ ). After drying over $\mathrm{MgSO}_{4}$ the organic layer was concentrated in vacuo. Flash column chromatography $\left(\mathrm{SiO}_{2}\right.$, $\mathrm{CH}_{2} \mathrm{Cl}_{2}$ /hexane, 1:1) or, if possible, recrystallization from $\mathrm{CH}_{2} \mathrm{Cl}_{2} / \mathrm{MeOH}$ gave pure 2 as a white powder in $67 \%$ yield, mp $241-243^{\circ} \mathrm{C}\left(\mathrm{CH}_{2} \mathrm{Cl}_{2} / \mathrm{MeOH}\right) .{ }^{1} \mathrm{H}$ NMR $\delta 7.83,7.70(2 \mathrm{~m}$, $8 \mathrm{H}, \mathrm{ArH}$-pht), $6.93,6.56(2 \mathrm{~s}, 8 \mathrm{H}$, o-tert-butyl ArH), 4.06, 3.90, $3.70\left(3 \mathrm{t}, 12 \mathrm{H}, J=7 \mathrm{~Hz}, \mathrm{OCH}_{2}\right.$ and $\left.\mathrm{NCH}_{2}\right), 4.36$ and $3.10(\mathrm{ABq}$, $8 \mathrm{H}, J=14 \mathrm{~Hz}, \mathrm{ArCH}_{2} \mathrm{Ar}$ ), 2.51 (quintet, $4 \mathrm{H}, J=7 \mathrm{~Hz}$, $\mathrm{CH}_{2} \mathrm{CH}_{2} \mathrm{~N}$ ), 1.88 (sextet, $4 \mathrm{H}, J=7 \mathrm{~Hz}, \mathrm{CH}_{2} \mathrm{CH}_{3}$ ), $1.20,0.91$ $\left(2 \mathrm{~s}, 36 \mathrm{H}\right.$, tert-butyl $\left.\mathrm{CH}_{3}\right), 0.85\left(\mathrm{t}, 6 \mathrm{H}, J=7 \mathrm{~Hz}, \mathrm{CH}_{2} \mathrm{CH}_{3}\right) ;{ }^{13} \mathrm{C}$ NMR $\delta 168.27(\mathrm{C}=\mathrm{O}), 153.99,152.9(\mathrm{ArC}-\mathrm{O}), 144.70,143.99$ $(\mathrm{ArC}-t-\mathrm{Bu}), 134.82,132.66,132.28\left(\mathrm{ArC}-\mathrm{CH}_{2}\right.$ and $\mathrm{ArC}-$ $\mathrm{C}=\mathrm{O}), 133.75,125.24,124.60,123.11(\mathrm{ArC}-\mathrm{H}$ calix and ArC-H Pht), 77.38, 72.54 (0-CH $)_{2}, 35.44\left(\mathrm{~N}-\mathrm{CH}_{2}\right), 33.94$, 33.64 $\left(\mathrm{C}-\left(\mathrm{CH}_{3}\right)_{3}\right), 31.60,31.27\left(\mathrm{C}-\left(\mathrm{CH}_{3}\right)_{3}\right), 31.15\left(\mathrm{CH}_{2}-\mathrm{Ar}\right)$, $29.77\left(\mathrm{CH}_{2}-\mathrm{CH}_{2} \mathrm{~N}\right), 23.48\left(\mathrm{CH}_{2}-\mathrm{CH}_{3}\right), 10.45\left(\mathrm{CH}_{3}\right)$; FAB-MS $\mathrm{m} / \mathrm{z} 1107$ ( $\mathrm{M}^{-}$, calcd 1106.6). Anal. Calcd for $\mathrm{C}_{72} \mathrm{H}_{86} \mathrm{~N}_{2} \mathrm{O}_{8}$ : C, $78.09 ; \mathrm{H}, 7.83 ; \mathrm{N}, 2.53$. Found: C, 78.32; H, 7.98; N, 2.58.

5,11,17,23-Tetranitro-25,27-dipropoxy-26,28-bis(3phthalimidopropoxy)calix[4]arene (3). To a solution of 3 $\mathrm{g}\left(2.71 \mathrm{mmol}\right.$ ) of 2 in $60 \mathrm{~mL}$ of $\mathrm{CH}_{2} \mathrm{Cl}_{2}$ was added $2.4 \mathrm{~mL}$ (31 $\mathrm{mmol}$ ) of trifluoroacetic acid. Subsequently $2.3 \mathrm{~mL}(55 \mathrm{mmol})$ of nitric acid ( $100 \%$ ) was added in portions upon which the mixture turned purple-black. After $10 \mathrm{~min}$ the reaction mixture was poured into icewater and diluted with $50 \mathrm{~mL}$ of $\mathrm{CH}_{2} \mathrm{Cl}_{2}$. The aqueous layer was extracted with $\mathrm{CH}_{2} \mathrm{Cl}_{2}(3 \times$ $50 \mathrm{~mL}$ ), and the combined organic layers were washed with brine $(3 \times 50 \mathrm{~mL})$, dried over $\mathrm{MgSO}_{4}$, and concentrated under reduced pressure. Recrystallization from $\mathrm{CH}_{2} \mathrm{Cl}_{2} / \mathrm{MeOH}$ afforded pure 3 in $98 \%$ yield, $\mathrm{mp} 169-17{ }^{\circ} \mathrm{C}(\mathrm{MeOH}) .{ }^{1} \mathrm{H}$

(13) Recently, thin planar waveguides of these compounds have been successfully applied in (a) Cerenkov-type second harmonic generation: Noordman, O. F. J.; van Hulst, N. F.; Bölger, B. J. Opt. Soc. Am. B. 1995, 12, 2398-2405. (b) Noncritically-phase-matched second harmonic generation using calix[4]arene-SiO $\mathrm{N}_{y}$ planar waveguides: Noordman, O. F. J.; Wörhoff, K.; van Hulst, N. F., submitted for publication. 
NMR $\delta 7.83,7.73(2 \mathrm{~m}, 8 \mathrm{H}, \mathrm{ArH}-\mathrm{pht}), 7.49,7.61\left(2 \mathrm{~s}, 8 \mathrm{H}, o-\mathrm{NO}_{2-}\right.$ $\mathrm{ArH}), 4.13,3.95,3.84\left(3 \mathrm{t}, 12 \mathrm{H}, J=7 \mathrm{~Hz}, \mathrm{OCH}_{2}\right.$ and $\left.\mathrm{NCH}_{2}\right)$, 4.52 and $3.40\left(\mathrm{ABq}, 8 \mathrm{H}, J=14 \mathrm{~Hz}, \mathrm{ArCH}_{2} \mathrm{Ar}\right.$ ), 2.28 (quintet $4 \mathrm{H}, J=7 \mathrm{~Hz}, \mathrm{CH}_{2} \mathrm{CH}_{2} \mathrm{~N}$ ), 1.88 (sextet, $4 \mathrm{H}, J=7 \mathrm{~Hz}, \mathrm{CH}_{2}$ $\left.\mathrm{CH}_{3}\right), 0.97\left(\mathrm{t}, 6 \mathrm{H}, J=7 \mathrm{~Hz}, \mathrm{CH}_{3}\right) ;{ }^{13} \mathrm{C} \mathrm{NMR} \delta 168.16(\mathrm{C}=\mathrm{O})$, $161.50(\mathrm{ArC}-\mathrm{O}), 142.99,142.82\left(\mathrm{ArC}-\mathrm{NO}_{2}\right), 135.61,135.21$ $\left(\mathrm{ArC}-\mathrm{CH}_{2}\right), 131.91(\mathrm{ArC}-\mathrm{C}=\mathrm{O}), 134.23,124.14,123.93,123.30$ (ArC-H calix and Pht), 78.00, $73.52\left(\mathrm{O}-\mathrm{CH}_{2}\right), 34.82\left(\mathrm{CH}_{2} \mathrm{~N}\right)$, $31.17\left(\mathrm{CH}_{2}-\mathrm{Ar}\right), 29.59\left(\mathrm{CH}_{2}-\mathrm{CH}_{2} \mathrm{~N}\right), 23.34\left(\mathrm{CH}_{2}-\mathrm{CH}_{3}\right), 10.16$ $\left(\mathrm{CH}_{3}\right)$; FAB-MS $\mathrm{m} / \mathrm{z} 1062.9$ (M-, calcd 1062.3). Anal. Calcd for $\mathrm{C}_{56} \mathrm{H}_{50} \mathrm{~N}_{6} \mathrm{O}_{16}: \mathrm{C}, 63.27 ; \mathrm{H}, 4.74 ; \mathrm{N}, 7.91$. Found: C, 62.93; $\mathrm{H}, 4.79 ; \mathrm{N}, 8.05$.

5,11,17,23-Tetranitro-25,27-dipropoxy-26,28-bis(3aminopropoxy)calix[4]arene (4). A suspension of $1.11 \mathrm{~g}$ (1.05 mmol) of 3 in $20 \mathrm{~mL}$ of THF and $80 \mathrm{~mL}$ of EtOH was refluxed for $3 \mathrm{~h}$ after addition of $1.0 \mathrm{~g}(19.4 \mathrm{mmol})$ of hydrazine hydrate. Upon cooling of the now clear orange solution, a white precipitate was formed. This precipitate was filtered off, the filtrate was concentrated in vacuo and taken up into $100 \mathrm{~mL}$ of $\mathrm{CH}_{2} \mathrm{Cl}_{2}$. After addition of $50 \mathrm{~mL}$ of $1 \mathrm{~N} \mathrm{NaOH}$ the mixture was stirred during $30 \mathrm{~min}$. After separation the organic layer was washed with $1 \mathrm{~N} \mathrm{NaOH}(2 \times 25 \mathrm{~mL})$ and brine $(2 \times 25 \mathrm{~mL})$ and dried over $\mathrm{MgSO}_{4}$. Evaporation of the solvent afforded 4 as a yellow powder in $93 \%$ yield, $\mathrm{mp} 209-$ $211{ }^{\circ} \mathrm{C}\left(\mathrm{CH}_{2} \mathrm{Cl}_{2}\right)$. ${ }^{\mathrm{t}} \mathrm{H}$ NMR $\delta 7.46,7.66(2 \mathrm{~s}, 8 \mathrm{H}, \mathrm{ArH}), 4.07$, $3.98\left(2 \mathrm{t}, 8 \mathrm{H}, J=7 \mathrm{~Hz}, \mathrm{OCH}_{2}\right), 4.51$ and $3.40(\mathrm{ABq}, 8 \mathrm{H}, J=14$ $\mathrm{Hz}, \mathrm{ArCH}_{2} \mathrm{Ar}$ ), $2.87\left(\mathrm{t}, 4 \mathrm{H}, J=7 \mathrm{~Hz}, \mathrm{CH}_{2} \mathrm{NH}_{2}\right.$ ), 2.01 (quintet, $4 \mathrm{H}, J=7 \mathrm{~Hz}, \mathrm{CH}_{2} \mathrm{CH}_{2} \mathrm{~N}$ ), 1.98 (sextet, $4 \mathrm{H}, J=7.5 \mathrm{~Hz}$, $\left.\mathrm{CH}_{2} \mathrm{CH}_{3}\right), 1.38\left(\mathrm{br} \mathrm{s}, 4 \mathrm{H}, \mathrm{NH}_{2}\right), 1.00\left(\mathrm{t}, 6 \mathrm{H}, J=7 \mathrm{~Hz}, \mathrm{CH}_{3}\right)$; ${ }^{13} \mathrm{C} \mathrm{NMR} \delta 161.35$ (ArC-O), 142.84( $\left.\mathrm{ArC}-\mathrm{NO}_{2}\right), 135.64,135.18$ $\left(\mathrm{ArC}-\mathrm{CH}_{2}\right), 124.21,123.81(\mathrm{ArC}-\mathrm{H}), 77.68,74.07\left(\mathrm{O}-\mathrm{CH}_{2}\right)$, $38.80\left(\mathrm{CH}_{2}-\mathrm{NH}_{2}\right), 33.66\left(\mathrm{CH}_{2}-\mathrm{CH}_{2} \mathrm{NH}_{2}\right), 31.14\left(\mathrm{Ar}-\mathrm{CH}_{2}\right)$, $23.24\left(\mathrm{CH}_{2}-\mathrm{CH}_{3}\right), 10.08\left(\mathrm{CH}_{3}\right) ;$ FAB-MS $m / z$ 804.2([M $\left.+\mathrm{H}\right]^{+}$, calcd 803.8); IR (KBr) 1355 and $1530\left(\mathrm{NO}_{2}\right), 3420\left(\mathrm{NH}_{2}\right) \mathrm{cm}^{-1}$; UV-vis $\left(\mathrm{CHCl}_{3}\right) \lambda_{\max }=292 \mathrm{~nm}, \epsilon=24 \times 10^{3} \mathrm{~L} \mathrm{~mol}^{-1} \mathrm{~cm}^{-1}$. Anal. Calcd for $\mathrm{C}_{40} \mathrm{H}_{46} \mathrm{~N}_{6} \mathrm{O}_{12} \cdot 1.7 \mathrm{H}_{2} \mathrm{O}: \mathrm{C}, 57.62 ; \mathrm{H}, 5.97 ; \mathrm{N}$, 10.08. Found: C, 57.41; H, 5.68; N, 9.72. Karl Fischer titration calcd for $1.7 \mathrm{H}_{2} \mathrm{O}: 3.68$. Found: 3.72 .

Polymerization. The calix[4]arene polyamic acid prepolymer (6) was obtained by stirring a solution of $30 \mathrm{~mL}$ of dry NMP, $3.0 \mathrm{~g}$ ( $3.74 \mathrm{mmol})$ of calix[4]arene diamine 4 and $1.66 \mathrm{~g}$ $(3.74 \mathrm{mmol})$ of hexafluorodisopropylidene diphthalic anhydride $(6 F D A, 5)$ for $14 \mathrm{~h}$ under argon. The reaction mixture was used in subsequent polyimidization reactions. IR (KBr) 3450 (br, $\mathrm{NH}$ and $\mathrm{OH}), 1680(\mathrm{COOH}), 1730(\mathrm{C}=\mathrm{O}$ amide $), 1530$ and $1360\left(\mathrm{NO}_{2}\right), 760\left(\mathrm{CF}_{3}\right) \mathrm{cm}^{-1}$.

Tetranitrocalix[4]arenepolyimide (7a): Thermal Polyimidization. A solution of polyamic acid prepolymer 6 in NMP and 10 vol \% of o-dichlorobenzene was refluxed (190$200^{\circ} \mathrm{C}$ ) for $11 \mathrm{~h}$. Water formed in the imidization was removed with a reverse Dean-Stark apparatus. The reaction mixture was poured into $300 \mathrm{~mL}$ of dry ice cooled EtOH under vigorously stirring. The resulting precipitate was filtered off, dissolved in THF $(20 \mathrm{~mL})$ and poured into hexane $(200 \mathrm{~mL})$. Again filtering off the precipitate and subsequently washing with diisopropyl ether $(3 \times 50 \mathrm{~mL})$ afforded polymer $7 \mathbf{a}$ as a gray powder. ${ }^{1} \mathrm{H}$ NMR (THF) $\delta 8.0-7.0\left(\mathrm{~m}, 8 \mathrm{H}+6 \mathrm{H}, 0-\mathrm{NO}_{2-}\right.$ ArH and ArH-phthalimido), $4.2-3.5$ (br m, $8 \mathrm{H}+4 \mathrm{H}, \mathrm{OCH}_{2}$ and $\left.\mathrm{CH}_{2}-\mathrm{Pht}\right), 4.4$ and $3.4\left(2 \times \mathrm{br} \mathrm{s}, 8 \mathrm{H}, \mathrm{ArCH}_{2} \mathrm{Ar}\right), 2.2(\mathrm{br} \mathrm{s}$, ?H, $\left.\mathrm{CH}_{2} \mathrm{NH}-\mathrm{C}=\mathrm{O}\right), 2.0-1.3\left(\mathrm{~m}, 4 \mathrm{H}+? \mathrm{H}, \mathrm{CH}_{2} \mathrm{CH}_{3}\right.$ and $\left.\mathrm{CH}_{2} \mathrm{CH}_{2} \mathrm{~N}\right), 0.9$ (br s, $\left.6 \mathrm{H}, \mathrm{CH}_{3}\right) ; \mathrm{UV}$-vis $\left(\mathrm{CH}_{2} \mathrm{Cl}_{2}\right) \lambda_{\max }=290$ $\mathrm{nm}, \epsilon=21 \times 10^{3} \mathrm{~L} \mathrm{~mol}^{-1} \mathrm{~cm}^{-1}$.

Tetranitrocalix [4]arenepolyimide (7b): Chemical Polyimidization. To a solution of poly(amic acid) prepolymer 6 in NMP was added $1.4 \mathrm{~g}$ of $\mathrm{Ac}_{2} \mathrm{O}, 0.5 \mathrm{~g}$ of pyridine, and $1.05 \mathrm{~g}$ of toluene. After stirring at $60^{\circ} \mathrm{C}$ for $20 \mathrm{~h}$, workup was carried out as described for $\mathbf{7 a}$. Pure polymer $\mathbf{7 b}$ was obtained as a white powder, ${ }^{1} \mathrm{H}$ NMR $\left(\mathrm{CD}_{2} \mathrm{Cl}_{2}\right) \delta 8.0-7.3(\mathrm{~m}, 8 \mathrm{H}+6 \mathrm{H}$, $o-\mathrm{NO}_{2} \mathrm{ArH}$ and ArH-pht), 4.2-3.8 (br m, $8 \mathrm{H}+4 \mathrm{H}, \mathrm{OCH}_{2}$ and $\mathrm{CH}_{2}-\mathrm{Pht}$ ), 4.48 and 3.36 (br ABq, $8 \mathrm{H}, J=14 \mathrm{~Hz}, \mathrm{ArCH}_{2} \mathrm{Ar}$ ), 2.29 (br m, $4 \mathrm{H}, \mathrm{CH}_{2} \mathrm{CH}_{2} \mathrm{~N}$ ), 1.89 (sextet, $4 \mathrm{H}, J=7.5 \mathrm{~Hz}$, $\left.\mathrm{CH}_{2} \mathrm{CH}_{3}\right), 0.93\left(\mathrm{t}, 6 \mathrm{H}, J=7 \mathrm{~Hz}, \mathrm{CH}_{3}\right) ; \mathrm{IR}(\mathrm{KBr}) 1780(\mathrm{C}=\mathrm{O}$, asym stretch), $1720(\mathrm{Ar}-\mathrm{C}=\mathrm{O}), 1355$ and $1530\left(\mathrm{NO}_{2}\right), 1385$, 1150 and 729 (imide ring) $\mathrm{cm}^{-1} ; \mathrm{UV}$-vis $\left(\mathrm{CH}_{2} \mathrm{Cl}_{2}\right) \lambda_{\max }=292$ $\mathrm{nm}, \epsilon=20 \times 10^{3} \mathrm{~L} \mathrm{~mol}^{-1} \mathrm{~cm}^{-1}$.
Film Preparation, Poling, and Measurements. Poled films were prepared at 20 and $50 \%$ relative humidity in a clean room with dust class 100 . A solution of $7 \mathbf{a}$ or $\mathbf{7 b}$ in cyclopentanone $(5-10$ and $25 \% \mathrm{w} / \mathrm{w}$ for thin and thick films, respectively) was spun on Pyrex glass (2 s, $200 \mathrm{rpm} ;>40 \mathrm{~s}, 1000-$ $2000 \mathrm{rpm}$ ), yielding films with thicknesses in the range $0.3-2$ $\mu \mathrm{m}$. These films were oriented at $150-230{ }^{\circ} \mathrm{C}$ for $15 \mathrm{~min}$ by corona poling $(25 \mu \mathrm{m}$ tungsten wire at a film distance of 10 $\mathrm{mm}$, corona voltage $9 \mathrm{kV}$, current $10 \mu \mathrm{A}$ ). The corona field was switched on after the poling temperature was reached. The films were allowed to cool to room temperature while the voltage was maintained. The orientation parameter $\cos ^{3} \theta$ of the films was calculated as described in ref 13 and varied between 0.2 and 0.3 . The SHG efficiencies of the films were measured with a Q-switched Nd:YAG laser at $1064 \mathrm{~nm}$ fundamental wavelength, using $\alpha$-quartz as a reference $\left(d_{11}\right.$ $=0.51 \mathrm{pm} \mathrm{V}^{-1}$.

Instrumentation. GPC analyses were performed with a Waters apparatus equipped with a PL-MIX column (Polymer Laboratories, UK) using DMF (HPLC grade)/LiBr/HOAc 99/ $0.5 / 0.5$ as eluent. This eluent was used to avoid partial adsorption of the polyamic acid groups to the gel. A mixture of polystyrenes (PL-mix-C of Polymer Laboratories UK) was used as reference. ${ }^{\mathrm{b}}$ TGA was performed on a Hi-Res TGA 2950 thermogravimetric analyzer (TA Instruments). Samples were heated under nitrogen from 20 to $600^{\circ} \mathrm{C}$ with a heating rate of $20^{\circ} \mathrm{C} / \mathrm{min}$. DSC was performed on a Perkin-Elmer DSC7 calorimeter with heating rates of 20 or $30^{\circ} \mathrm{C}$.

\section{Results and Discussion}

Synthesis of Calix[4]arene-Based Polymers. ${ }^{14}$ To enable the covalent incorporation of the NLO active calix[4]arene in a polyimide chain, it was necessary to modify the tetrapropoxytetranitrocalix[4]arene with two amino functionalities. Therefore the diamino functionalized derivative 4 was synthesized (Scheme 1). The starting compound 5,11,17,23-tetra-tert-butyl-25,27dipropoxycalix[4]arene $\mathrm{e}^{10,15}(\mathbf{1})$ was alkylated with $N$-(3bromopropyl)phthalimide in DMF using $\mathrm{NaH}$ as the base, affording 5,11,17,23-tetra-tert-butyl-25,27-dipropoxy-26,28-bis(3-phthalimidopropoxy)calix[4]arene (2) in $67 \%$ yield. Subsequent ipso nitration with a mixture of trifluoroacetic acid (TFA) and $100 \% \mathrm{HNO}_{3}$ gave $5,11,17,23$-tetranitro-25,27-dipropoxy-26,28-bis (3phthalimidopropoxy)calix[4]arene (3) in $98 \%$ yield. ${ }^{16}$ The protecting phthalimido groups were then removed with hydrazine, yielding $93 \%$ of the tetranitrocalix[4]arene diamino monomer (4).

For the solubility of polyimides the structure of the dianhydride linker is very important. We have selected the hexafluoroisopropylidene diphthalic anhydride unit $(6 \mathrm{FDA}, \mathbf{5})$ as this linker is known to yield polyimides of good solubility with still high $T_{\mathrm{g}} \cdot 8,17$ Furthermore 6FDA

(14) Only two examples of polymers with covalently bound calix[4]arenes (non-NLO active) have been described in the literature. A calix[4]arene methacrylate oligomer with an average molecular weight of $6.7 \mathrm{kDa}$ (ca. 6 calix[4]arene units) has been prepared by McKervey et al. (Harris, S. J.; Barrett, G.; McKervey, A. J. Chem. Soc, Chem. Commun. 1991, 1224). The same monomethacrylate calix[4]arene tetraester monomer has been incorporated in a methacrylate functionalized polysiloxane in our group (Brunink, J. A. J.; Lugtenberg, R. J. W.; Brzózka, Z.; Engbersen, J. F. J.; Reinhoudt, D. N. J. Electroanal. Chem. 1994, 378, 185-200) for application as an ionselective membrane on chemically modified field effect transistors. Glass transition temperatures were not reported for both polymers, but because of the flexibility of the polymer backbones the $T_{\mathrm{g}}$ 's will be too low to obtain thermally stable NLO films after incorporation of NLO active calix[4]arenes.

(15) Iwamoto, K.; Yanagi, A.; Araki, K.; Shinkai, S. Chem. Lett. $1991,473$.

(16) Verboom, W.; Durie, A.; Egberink, R. J. M.; Asfari, Z.; Reinhoudt, D. N. J. Org. Chem. 1992, 57, 1313.

(17) Huang, S. J.; Hoyt, A. E. TRIP 1995, 3, 262. 
Scheme 1. Synthesis of Calix[4]arene Diamine Monomer $4^{a}$
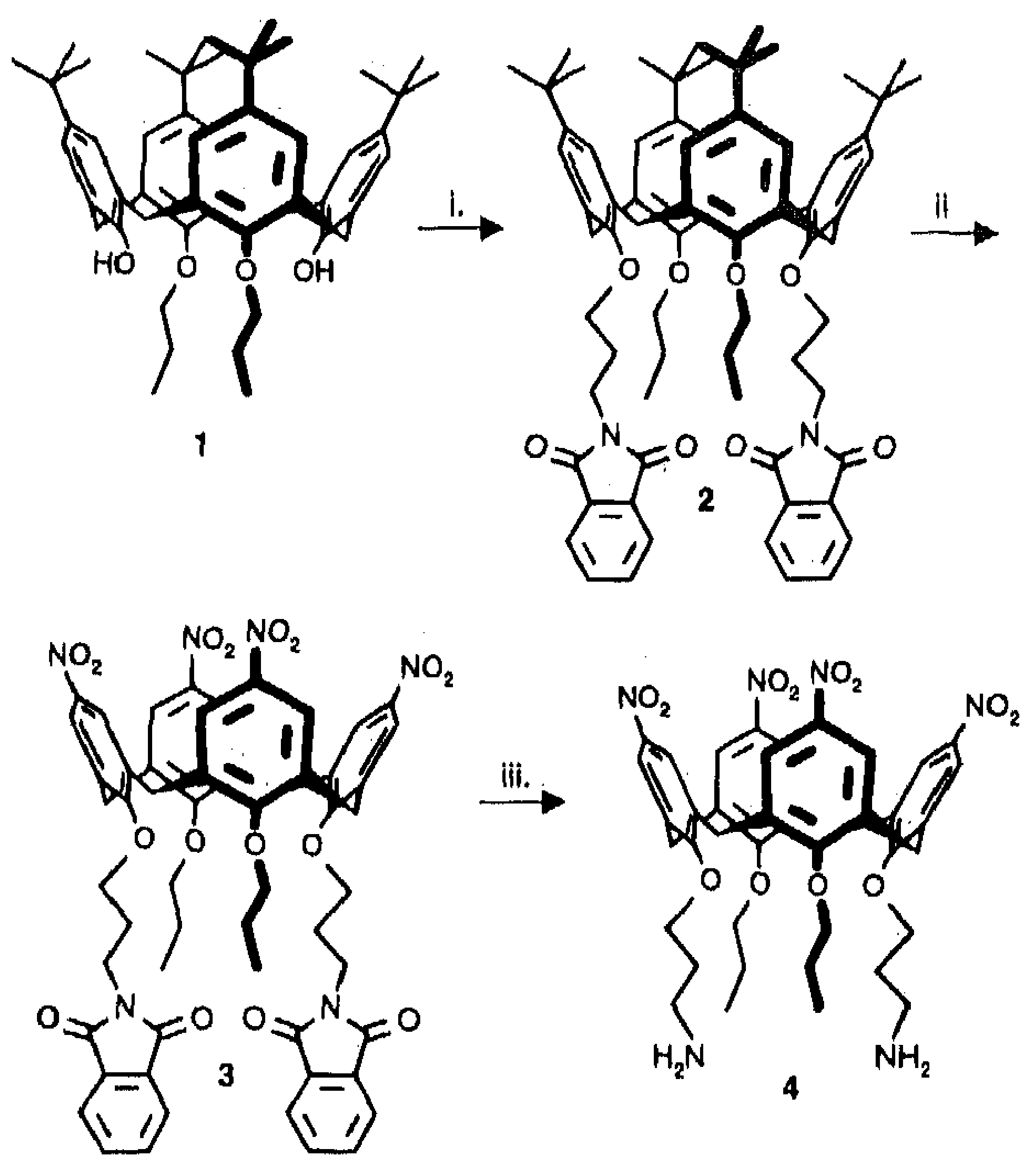

a (i) $\mathrm{NaH}, N$-(3-bromopropyl)phthalimide, DMF, $20 \mathrm{~h}, 70^{\circ} \mathrm{C}$. (ii) TFA, $100 \% \mathrm{HNO}_{3}, \mathrm{CH}_{2} \mathrm{Cl}_{2}, 10 \mathrm{~min}$, room temperature. (iii) $\mathrm{H}_{2} \mathrm{NNH}_{2} \cdot \mathrm{H}_{2} \mathrm{O}$, THF, EtOH, $4 \mathrm{~h}$, reflux.

derived polyimides can yield transparent and low birefrigent films after spin-coating, 8,17 Poly(amic acid) prepolymer 6 was prepared by reacting calix diamine 4 and dianhydride 5 in dry $N$-methyl-2-pyrrolidinone (NMP) (Scheme 2 ). Subsequently, two routes to imidization of the polymer were investigated. A thermal imidization to polyimide $\mathbf{7 a}$ was performed in $o$-dichlorobenzene by the azeotropic removal of water at 190 ${ }^{\circ} \mathrm{C} ., 18$ Chemical imidization to polyimide $\mathbf{7 b}$ was achieved by reaction of polyamic acid 6 in NMP with acetic anhydride, using pyridine as an organic base ${ }^{8,19}$

Polymer Characterization. Polyamic acid 6 and polyimides $7 \mathbf{a}$ and $7 \mathbf{b}$ were characterized by IR and ${ }^{1} \mathrm{H}$ NMR spectroscopy. Polyamic acid 6 exhibits a typical amide carbonyl absorption at $1730 \mathrm{~cm}^{-1}$ and a broad carboxylic carbonyl absorption at $1675 \mathrm{~cm}^{-1}$. The thermally imidized polymer $7 \mathbf{a}$ shows typical absorptions for a polyimide ring at 729,1150 , and $1385 \mathrm{~cm}^{-1}$ and the asymmetric and symmetric aromatic imide carbonyl stretch absorptions at 1780 and $1720 \mathrm{~cm}^{-1} .20$ In addition major peaks at 1730 and $1675 \mathrm{~cm}^{-1}$ were apparent, indicating the presence of considerable amounts of unreacted amic acid groups. In the infrared spectrum of the chemically imidized polymer $\mathbf{7 b}$ only the typical absorptions for a polyimide ring and the aromatic imide carbonyl stretch absorptions, as given above, are present. The presence of the unreacted amic acid groups in polymer $\mathbf{7 a}$ is also indicated by the poor solubility of this polymer. Like polyamic acid $\mathbf{6}$, polymer $\mathbf{7 a}$ is soluble only in polar solvents such as THF or DMSO, whereas polymer $\mathbf{7 b}$ is well soluble in a variety

(18) Jou, J.-H.; Huang, P.-T. Macromolecules 1991, 24, 3796-3803. (19) Beuhler, A. J.; Wargowski, D. A. United States Patent No. US005317082A, 1994.

(20) Yang, S.; Peng, Z; Yu. L. Macromolecules 1994, 27, 2638-2640. Peng, Z; Yu, L. Ibid. 5858-5862.
Scheme 2. Polymerization ${ }^{a}$
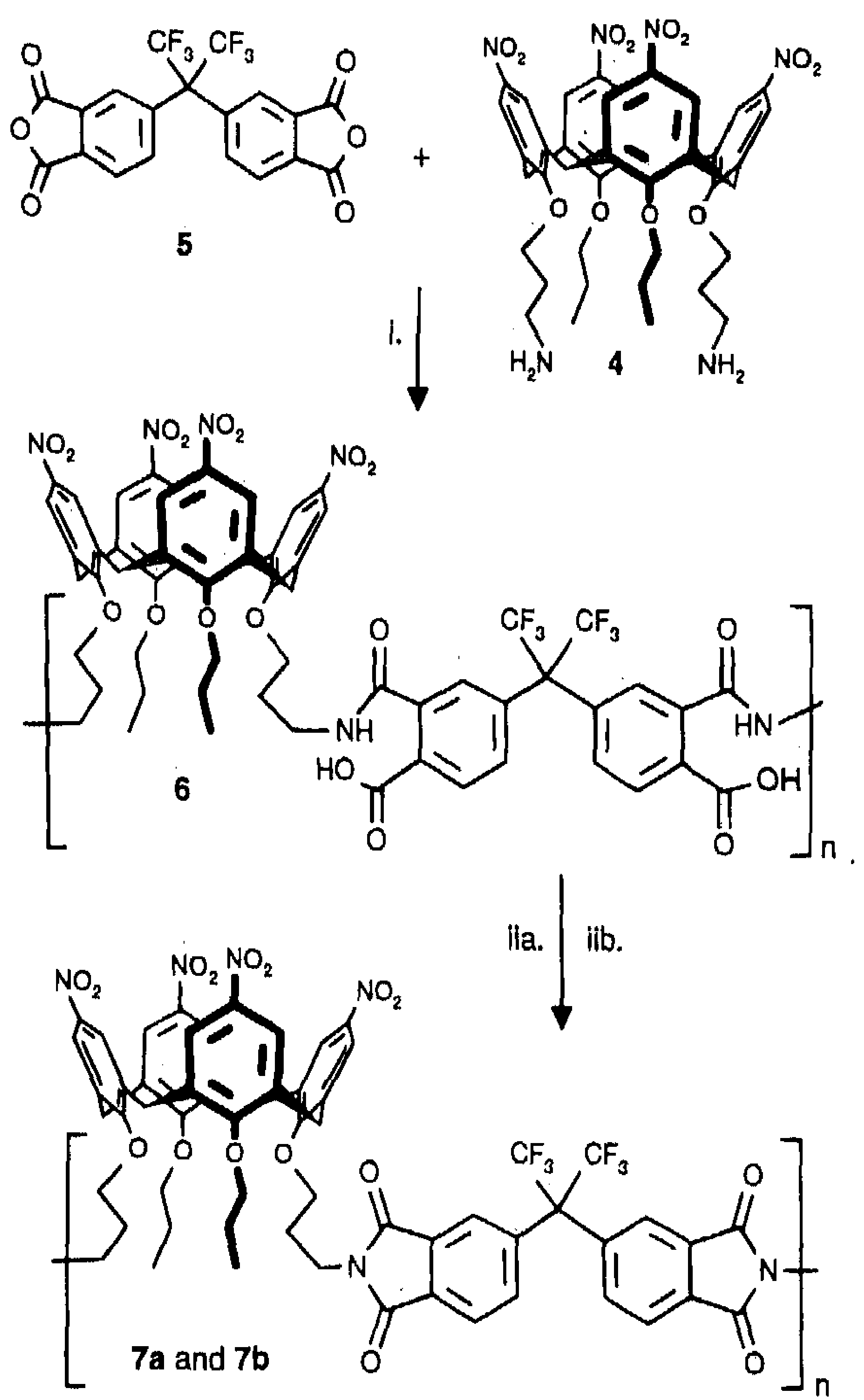

a (i) NMP, $14 \mathrm{~h}$, room temperature. (iia) o-dichlorobenzene, 11 $\mathrm{h}, 190-200^{\circ} \mathrm{C}$. (iib) $\mathrm{Ac} 2 \mathrm{O}$, pyridine, toluene, $14 \mathrm{~h}, 60^{\circ} \mathrm{C}$.

of organic solvents. The complete imidization in $\mathbf{7 b}$ can also be concluded from the ${ }^{1} \mathrm{H}$ NMR spectrum where the signal of the methylene group linked to the amino group has shifted from $2.9 \mathrm{ppm}$ in the calix[4]arene diamino monomer (4) to $3.8 \mathrm{ppm}$ after imidization. This shift of $0.9 \mathrm{ppm}$ is in accordance with data reported in the literature. ${ }^{20}$ Due to broadening and overlap of peaks, the different amide and carboxylic acid resonances of $\mathbf{6}$ and $\mathbf{7 a}$ are difficult to assign.

Gel permeation chromatography (GPC) gave molecular weights $\left(M_{\mathrm{w}}\right)$ of 43 and $56 \mathrm{kDa}$ for $\mathbf{7 a}$ and $7 \mathbf{b}$, respectively, which indicates that an average of ca. 40 and 50 calix[4]arene units are connected. Both polymers have a rather similar molecular weight distribution of 1.95 and 1.91, respectively.

It is known that the glass transition temperatures of polyimides are usually high $\left(200-400^{\circ} \mathrm{C}\right)$ and difficult to measure in differential scanning calorimetry (DSC), ${ }^{21}$ For 7 a a large uptake of heat from $190^{\circ} \mathrm{C}$ (the thermal imidization temperature) to $240^{\circ} \mathrm{C}$ is observed during the first heating run (Figure 1) which can be attributed to further imidization. The second DSC run of $7 \mathbf{a}$ is similar to the DSC runs of $7 \mathbf{b}$ and shows a minor phase transition at $238^{\circ} \mathrm{C}$. This probably reflects the $T_{\mathrm{g}}$ of the fully imidized polymer. Also a thermal gravity analysis (TGA) of 7a points to further imidization upon initial heating, since a loss of weight of $1.12 \%$ was

(21) Ghassemi, H.; Hay, A. S. Macromolecules 1994, 27, 3116-3118. 


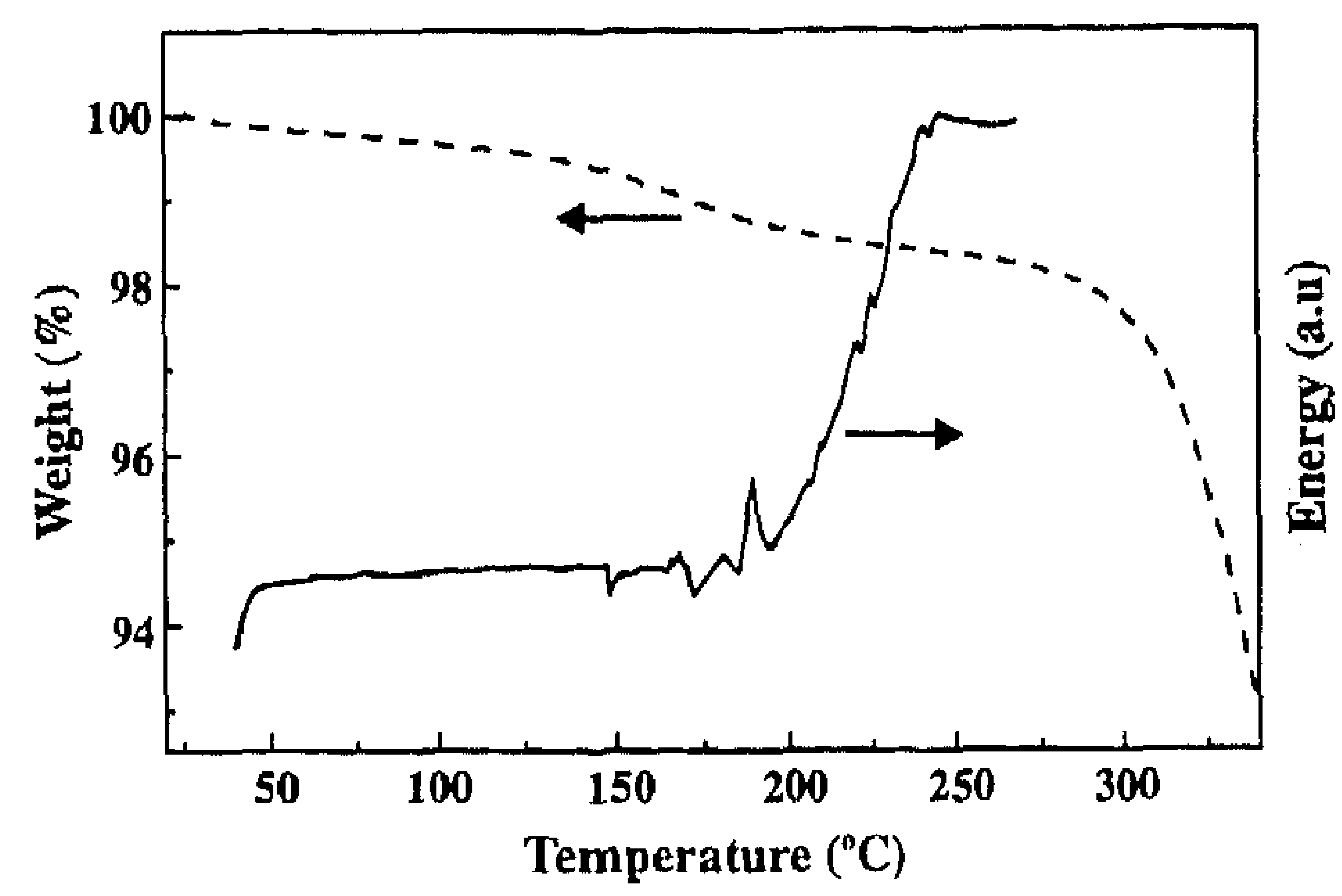

Figure 1. DSC curve (solid line) and TGA curve (dashed line) of $7 \mathbf{a}$.

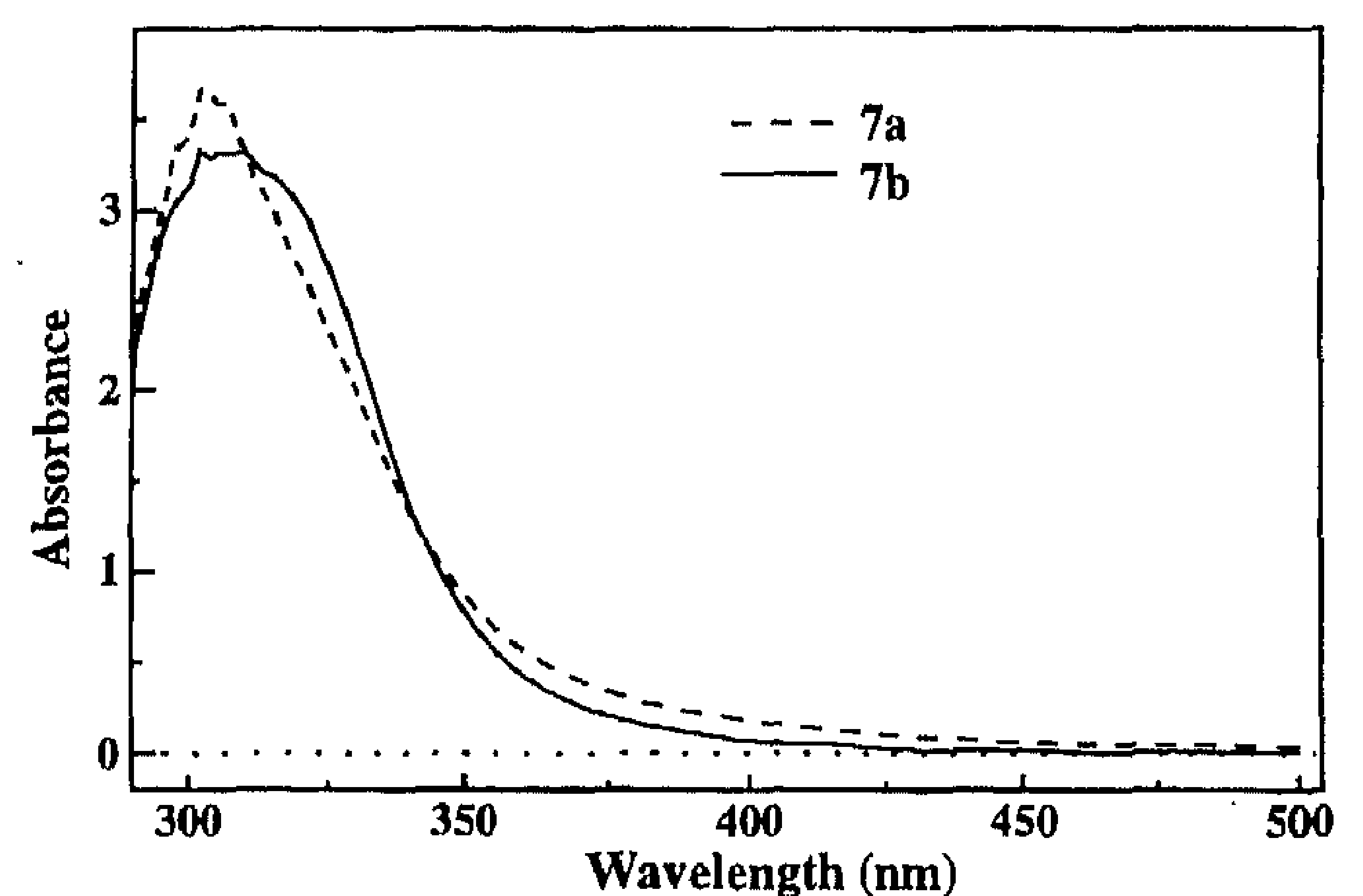

Figure 2. UV-vis spectra of thin films of $7 \mathbf{a}$ and $7 \mathbf{b}$ (before poling).

observed between 130 and $240{ }^{\circ} \mathrm{C}$ (Figure 2), corresponding to 0.76 equiv of water. Above $300{ }^{\circ} \mathrm{C}$ the polymer starts to decompose.

(Non-)linear Optical Properties. Oriented thin films of $\mathbf{7 a}$ and $\mathbf{7 b}$ were prepared on glass substrates by spin-coating from cyclopentanone solution, followed by electric field poling. The calixarene imide polymers give smooth, physically stable, and highly transparent films of thicknesses ranging from 0.2 to $2.2 \mu \mathrm{m}$, depending on the spinning speed and the concentration of the cyclopentanone solution. Films that were obtained earlier ${ }^{11}$ from pure (tetranitrotetrapropoxy)calix[4]arene were only $0.3 \mu \mathrm{m}$ thick, fragile, and gave scattering of light. The transparency of films of $\mathbf{7 a}$ and $\mathbf{7 b}$ is illustrated by the absorption spectra shown in Figure 2 . Because of the low $\lambda_{\text {cutoff }}$ values of 410 and $450 \mathrm{~nm}$, respectively, off-resonance frequency doubling from 1064 to $532 \mathrm{~nm}$ or even from 820 to $410 \mathrm{~nm}$ is possible. 22

Important for the practical use of NLO-active polymers is their long-term stability. Therefore various poling and curing conditions were investigated after films were poled for $15 \mathrm{~min}$, at 150 , at 230 , or at $150^{\circ} \mathrm{C}$ after $2 \mathrm{~h}$ of thermal curing at $150^{\circ} \mathrm{C}$. The frequencydoubling coefficient $d_{33}(1064 \mathrm{~nm})$ of the thus obtained films of $7 \mathbf{a}$ and $7 \mathbf{b}$ varied between 2.3 and $4.0 \mathrm{pm} \mathrm{V}^{-1}$. 23

Figures 3 and 4 show the stability of the frequencydoubling coefficient $d_{33}$ for the films of $7 \mathbf{a}$ and $\mathbf{7 b}$ prepared under different poling conditions and stored at room temperature or at $80^{\circ} \mathrm{C}$. Films stored at room temperature all show a stable NLO activity after an

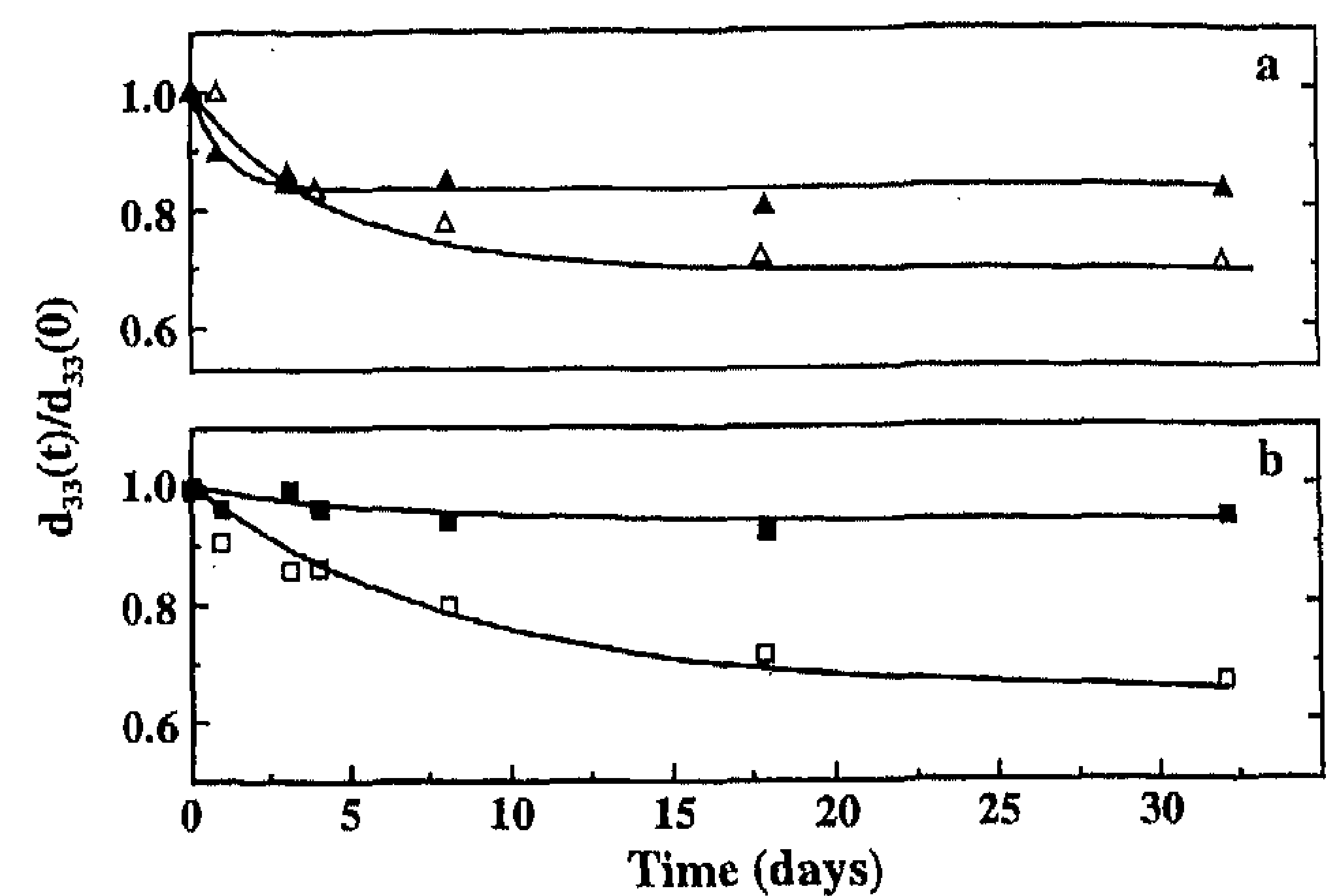

Figure 3. Stability of frequency doubling coefficient $d_{33}$ of differently prepared films of $\mathbf{7 a}$ stored at room temperature (solid symbols) and at $80{ }^{\circ} \mathrm{C}$ (open symbols). (a) $30 \mathrm{~min}$ thermally cured at $2300^{\circ} \mathrm{C}$ and poled at $230^{\circ} \mathrm{C}$; (b) poled at $150^{\circ} \mathrm{C}$.

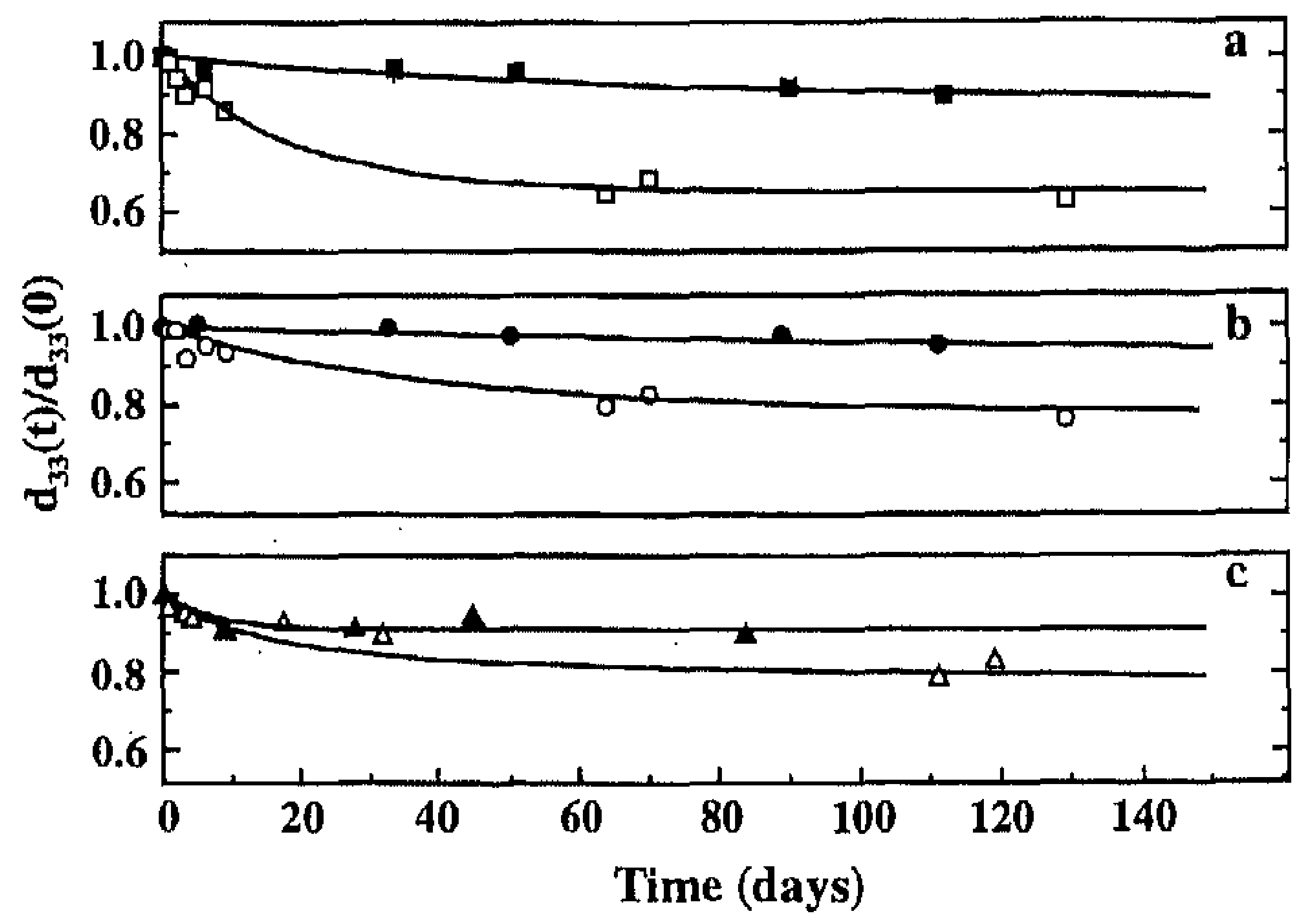

Figure 4. Stability of frequency-doubling coefficient $d_{33}$ of differently prepared films of $\mathbf{7 b}$ stored at room temperature (solid symbols) and at $80^{\circ} \mathrm{C}$ (open symbols): (a) poled at 150 ${ }^{\circ} \mathrm{C}$; (b) poled at $230^{\circ} \mathrm{C}$; (c) $2.5 \mathrm{~h}$ thermally cured at $150{ }^{\circ} \mathrm{C}$ and poled at $150^{\circ} \mathrm{C}$.

Table 1. Molecular Weights and Glass Transition Temperatures of $7 \mathrm{a}$ and $7 \mathrm{~b}$

\begin{tabular}{ccccccc}
\hline polymer & $\begin{array}{c}M_{\mathrm{w}} \\
(\mathrm{kDa})\end{array}$ & $\begin{array}{c}M_{\mathrm{n}} \\
(\mathrm{kDa})\end{array}$ & polydispersity & $\begin{array}{c}T_{\mathrm{g}} \\
\left({ }^{\circ} \mathrm{C}\right)\end{array}$ & $\begin{array}{c}\lambda_{\max } \\
(\mathrm{nm})\end{array}$ & $\begin{array}{c}\lambda_{\text {cutor }} \\
(\mathrm{nm})\end{array}$ \\
\hline $7 \mathrm{a}$ & 43.2 & 22.1 & 1.95 & & 290 & 450 \\
$7 \mathrm{~b}$ & 56.1 & 29.3 & 1.91 & 238 & 292 & 410
\end{tabular}

initial decay of $15 \%$ or less (Figures 3 and 4 ). When stored at $80^{\circ} \mathrm{C}$, the film of $7 \mathrm{a}$ which was cured and poled at $230^{\circ} \mathrm{C}$ shows a stable NLO activity of $2.3 \mathrm{pm} / \mathrm{V}$ after an initial decay of $30 \%$ (Figure $3 \mathrm{a}$ ). The film poled at $150{ }^{\circ} \mathrm{C}$, however, shows a decay of more than $30 \%$

(22) Noordman et al. have shown that with neat films of (tetranitrotetrapropoxy)calix[4]arene frequency doubling from 820 to $410 \mathrm{~nm}$ is possible with efficiencies up to $0.23 \%$ over a path length of $6 \mathrm{~mm}$ in a Cerenkov-type device. ${ }^{13 a}$ Efficiencies of that order of magnitude and higher ( 2 orders of magnitude is feasible ${ }^{13 a}$ ) should also be obtainable with the polymer films $7 \mathbf{a}$ and $7 \mathbf{b}$ since the absorption properties of these films are, as expected, similar to or even better than the neat calix[4]arene films used in the Cerenkov-type devices. Noordman et al. have also studied noncritically-phase-matched second harmonic generation using calix[4]arene- $\mathrm{SiO}_{x} \mathrm{~N}_{y}$ planar waveguides. ${ }^{13 b}$ In this work they show that frequency doubling to $450 \mathrm{~nm}$ with a maximal efficiency of $0.9 \%$ is possible when using a fundamental peak power of $500 \mathrm{~W}$. Furthermore an optical loss of $1 \mathrm{~dB} / \mathrm{mm}$ was observed at 458 $\mathrm{nm}$. On the basis of the results obtained for these planar calix[4]arene$\mathrm{SiO}_{x} \mathrm{~N}_{y}$ waveguides, it is shown by calculations that normalized efficiencies of $7.5 \% \mathrm{~W}^{-1}$ (corrected for nonuniformity and absorption) could be obtained in a $10 \mathrm{~mm}$ long device by using a $5 \mu \mathrm{m}$ channel waveguide instead of a planar waveguide. 
after 30 days, and even after this period no stable value is reached (Figure $3 \mathrm{~b}$ ). Thus, to obtain stable films of $7 \mathbf{a}$, thermal curing prior to the poling process is essential. This thermal curing promotes further imidization and rigidification of the polymer, thereby prohibiting the relaxation of the aligned calixarenes in the polymer matrix.

All films of $\mathbf{7 b}$ are stable at $80^{\circ} \mathrm{C}$ after some initial decay has occurred (Figure 4). Poling close to the glass transition temperature or extensive thermal curing prior to poling is advantageous for the NLO stability of films of $\mathbf{7 b}$ as is shown by the relative NLO activity curves in Figure 4.

(23) The $d_{33}$ values in these polymers are two to three times lower compared to the value of $7.3 \mathrm{pm} \mathrm{V}^{-1}$ for films of neat (tetranitrotetrapropoxy)calix[4]. arene. ${ }^{11}$ This can be attributed to the $20 \%$ lower chromophore density caused by the presence of the polyimide linker and to the lower degree of alignment of the chromophores caused by the restricted rotational freedom of the covalently linked NLO active calix[4] ]arenes in the polymer ( $\cos ^{3} \theta<0.3$ in the polyimide films and 0.6 in noal films). The use of calix[4] arene derivatives with higher $\beta$ values such as tetrakis ( $p$-nitrostilbene)tetrapropoxycalix[4]arene can potentially further enhance the SHG efficiency as neat films of these compounds have $d_{33}$ values of $25-40 \mathrm{pm} \mathrm{V}^{-1}, 11,12$

\section{Conclusions}

Calix[4]arene polyimides of high processability have been synthesized by reaction of bis(3-aminopropoxy)dipropoxytetranitrocalix[4]arenes with hexafluoroisoproylidene diphthalic anhydride. After spincoating, the calix[4]arene chromophores in these polymers can be efficiently poled, yielding highly transparent $(>400 \mathrm{~nm}$ ) NLO active films. Both thermally (7a) and chemically $(7 \mathrm{~b})$ imidization of the polyamic acid prepolymer 6 yields polyimides of high thermal NLO stability when treated under the proper poling conditions. This makes these calix[4]arene polyimides promising for frequency-doubling applications.

Acknowledgment. We thank T. W. Stevens and A. M. Montanaro-Christenhusz of the Department of Chemical Analysis for recording the mass spectra and performing the elemental analyses, respectively. This investigation was financially supported by the $\mathrm{OSF}$ program Micro Optics at the University of Twente and by Akzo Nobel Electronic Products, Arnhem, The Netherlands.

CM960420G 